the equipment was set out after sunset to avoid human and domestic animal interference. We felt that although replicate islands would have enhanced the study, the subsequet bias of our later evening activity in setting tiles and traps would inject much bias by possibly affecting rodent and shrew movement patterns.

Acknowlegdements: We thank Daniel Thompson (Denver Wildlife Research Center) for reviewing this manuscript. This study was financially supported by the Bangladesh Agricultural Research Institute and the United States Agency for International Development under the project "Agricultural Research Vertebrate Pest Component" PASA ID/BNG-0003-1-78.

\title{
REFERENCES
}

Hayne D. W., 1949: Two methods for estimating population from trapping records. J. Mammal., 30: 399-411. - Lord R. D., Vilches A. M., Maiztegui J. I. \& Soldini C. A., 1970: The tracking board: a relative census technique for studying rodents. J. Mammal., 51: 828-829. - Marten G. G., 1972: Censusing mouse populations by means of tracking. Ecology, 53: 859-867. - Smith M. H., Gardner R. H., Gentry J. B., Kaufman D. W. \& O'Farrell M. H., 1975: Density estimations of small mammal populations. [In: "Small mammals: their productivity and population dynamics", F. B. Golley, K. Petrusewicz, L. Ryszkowski, eds.]. Cambridge Univ. Press: 25-53. London. - Southern H. N., 1965: The trapline index to small mammal populations. J. Zool. (London), 147: 217-221. - Stickel L. F., 1948: The trap line as a measure of small mammal populations. J. Wildl. Manage., 12: 153-161. - Tamarin R. H., 1977: Reproduction in the island beach vole, Microtus breweri, and the mainland meadow vole, Microtus pennsylvanicus, in southeastern Massachusetts. J. Mammal, 58: 536-548. - West R. R., Fall M. W. \& Benigno E. A., 1976: Comparison of tracking tiles and snap traps for obtaining population indices of Rattus rattus mindanensis in the Philippines. Philipp. Agric., 59: 379-386. Zippin C., 1958: The removal method of population estimation. J. Wildl. Manage., 22: $82-90$.

Accepted, October 4, 1984.

\section{Relative Capture Efficiency of Large and Small Sherman Live Traps}

WZGLEDNA EFEKTYWNOSC MAEYCH I DUZYCH ZYWOEOWEK SHERMANA

\section{Mark S. MALY \& Jack A. CRANFORD}

Maly M. S. \& Cranford J. A., 1985: Relative capture efficiency of large and small Sherman live traps. Acta theriol., 30, 8: 165-167 [With 1 Table]

In a study of small mammal populations on Assateague Island, Virginia, U.S.A., two species (Microtus pennsylvanicus, Oryzomys palustris) exhibited a significant preference for large rather than small Sherman live traps. Three smaller species (Cryptotis parva, Mus musculus, Peromyscus leucopus) did not show a significant bias with 
respect to trap size. Differential effectiveness of large and small traps appeared to be related to size-specific behavioral responses and not to differences in trap sensitivity.

(Dept. of Biology, Virginia Polytechnic Institute and State University. Blacksburg, Virginia, 24061)

\section{INTRODUCTION}

Numerous authors have reported on the relative efficiency of different types of small mammal traps (e.g., Rose et al., 1977, Mihok et al., 1982, Williams \& Braun, 1983). However, only two studies have compared different sizes of the Sherman live trap, the type most commonly used by American researchers. Quast \& Howard (1953) found large $(254 \times 76 \times$ $\times 76 \mathrm{~mm}$ ) Sherman-type traps to be much more effective than small $(164 \times 64 \times 51 \mathrm{~mm})$ traps in capturing Peromyscus species in the San Joaquin Experimental Range, O'Neals, California. In contrast, Dalby \& Straney (1976) found small Sherman live traps to greatly exceed large traps in numbers of white-footed mice (Peromyscus leucopus) captured in woodlands near Blacksburg, Virginia. In this report, we document the relative efficiency of large and small Sherman live traps in capturing five species of small mammals (including white-footed mice) on Assateague Island, Virginia, U.S.A.

Table 1

Captures of small mammals in small and large Sherman live traps

\begin{tabular}{|c|c|c|c|c|c|c|}
\hline \multirow[b]{2}{*}{ Species } & \multirow[b]{2}{*}{$\begin{array}{c}\text { Number of } \\
\text { indiv. }\end{array}$} & \multicolumn{4}{|c|}{ Captures } & \multirow[b]{2}{*}{$P$-value } \\
\hline & & $\begin{array}{l}\text { Mean } \\
\text { wt., g }\end{array}$ & $\begin{array}{l}\text { Large } \\
\text { traps }\end{array}$ & $\begin{array}{l}\text { Small } \\
\text { traps }\end{array}$ & $x^{2}$ & \\
\hline Least shrew & 30 & 4.1 & 15 & 18 & 0.27 & NS \\
\hline House mouse & 67 & 12.4 & 47 & 55 & 0.63 & NS \\
\hline Meadow vole & 85 & 40.0 & 117 & 88 & 4.10 & $<.05$ \\
\hline Rice rat & 80 & 46.6 & 97 & 62 & 7.70 & $<.0 .1$ \\
\hline White-footed mouse & 15 & 17.7 & 15 & 16 & 0.13 & NS \\
\hline Meadow jumping mous & se 4 & 12.3 & 2 & 2 & 0.00 & - \\
\hline
\end{tabular}

\section{METHODS}

As part of a study on small mammal competition and resource utilization, trapping was conducted at biomonthly intervals from August 1983 to Januaryl 1984. During each trapping period, one large $(279 \times 89 \times 76 \mathrm{~mm})$ folding and one small $(165 \times 64 \times 51 \mathrm{~mm})$ nonfolding Sherman live trap were placed at each of 243 trap stations located in three 9 station by 9 station permanent trapping. grids. These grids encompassed dune grassland, freshwater marsh, pine woodland, shrub, and salt marsh habitats (Higgins et al., 1971) on Chincoteague IVational Wildlife Refuge, Assateague Island, Virginia, U.S.A. Traps were baited with rolled oats and checked twice daily for five days during each trapping period. Both traps at a trap station were located in similar microhabitats and near evidence of small mammal activity (e.g., runways, plant clippings) whenever possible. A total of 9720 trap nights were completed during the study.

\section{RESULTS}

We captured six species of small mammals for a total of 535 captures (281 individuals). Three species, least shrews (Cryptotis parva), house 
mice (Mus musculus), and white-footed mice (Peromyscus leucopus), showed no significant trend with respect to large and small traps (Table 1). Rice rats (Oryzomys palustris) and meadow voles (Microtus pennsylvanicus) were captured significantly more often by large traps than by small traps. Meadow jumping mice (Zapus hudsonius) were) captured too infrequently to establish a trend with respect to trap size. The relative efficiency of large and small traps in capturing small mammals did not differ significantly among different trapping periods $(\chi=4.15, P>0.20)$.

\section{DISCUSSION}

Our results indicate that large and small Sherman live traps are equally effective in capturing the smaller mammals species (mean wt $4-18 \mathrm{~g}$ ) while the larger species (mean wt $40-47 \mathrm{~g}$ ) were more readily caught in large traps. These findings differ considerably with those of Dalby \& Straney (1976) who reported greater efficiency of small traps in capturing white-footed mice. Dalby \& Straney concluded that the lower effectiveness of large traps resulted from greater treadle insensitivity to smaller (lighter) mammals. We found no evidence to lower treadle sensitivity in large or small traps since even $4 \mathrm{~g}$ least shrews were caught equally well by either size trap. Therefore, the greater effectiveness of large traps in capturing meadow voles and rice rats was probably due to differential behavioral responses by these species to differently-sized traps.

Acknowledgements: This research was supported by a Virginia Academy of: Since Grant and a NSF Graduate Fellowship awarded to M. S. Maly. The staff of Chincoteague National Wildlife Refuge provided permission to trap and logistic support. The Department of Biology at Virginia Polytechnic Institute and State University provided computing funds and clerical support.

\section{REFERENCES}

Dalby P. L. \& Straney D. O., 1976: The relative effectiveness of two sizeof Sherman live traps. Acta theriol., 21: 311-313. - Higgins E. A. T., Rappleye R. D. \& Brown R. G., 1971: The flora and ecology of Assateague Island. Univ. of Maryland Agric. Exp. Sta. Bull. A-172. - Mihok S., Boonstra R., Rodd F. H. \& Schwartz B., 1982: Response of Microtus pennsylvanicus to multiple-capture traps. Can. J. Zool., 60: 2965-2967. - Quast J. C. \& Howard W. E., 1953: Comparison of catch of two sizes of small-mammal live traps. J. Mammal., 34: 514-515. Rose R. K., Slade N. A. \& Honacki J. H., 1977: Live trap preference among grassland mammals. Acta theriol., 22: 296-307. - Williams D. F. \& Braun S. E., 1983: Comparison of pitfall and conventional traps for sampling small mammal populations. J. Wildl. Manage., 47: 841-845.

Accepted, August 1, 1984. 